\title{
Accuracy and Reliability of Methods to Measure Marginal Adaptation of Crowns and FDPs: a literature review
}

Abstract: Purpose: To review methods used to investigate marginal adaptation of crowns and fixed dental prostheses, and discuss testing variables employed and their influence on results. Methods: Online libraries including PubMed, Scopus and Ovid, were searched for articles evaluating the marginal adaptation of crowns and FDPs using combination of keywords:"marginal accuracy", "marginal fit", "marginal gap", "marginal discrepancy", “fitting accuracy", "crown" and "FPD". Peer-reviewed publications in English in the period 1970 to December 2011 were collected, evaluated by their abstract, and included if they met the inclusion criteria. The criteria involved studies evaluating marginal adaptation of crowns and fixed dental prostheses through clear experimental protocols. Exclusion criteria involved longitudinal prospective and retrospective clinical evaluations, studies using subjective tactile sensation; and other predefined criteria. Results: 277 papers were identified and only 183 met the inclusion criteria. Direct view technique was used by $47.5 \%$ of the articles followed by cross-sectioning (23.5\%) and impression replica (20.2\%) techniques. The marginal gap values reported by these techniques varied among individual crown system and across different systems because of variations in studies type (in-vivo vs in-vitro), sample size and measurements per specimen, finish line design, and stage at which the marginal gap was measured. Conclusion: There was a substantial lack of consensus relating to marginal adaptation of various crowns systems due to differences in testing methods and experimental protocols employed. Direct view technique was the most commonly used method of reproducible results. Also, conducting an experimental set-up of testing a minimum of 30 specimens at 50 measurements per specimen should produce reliable results. Additionally, using a combination of two measurement methods can be useful in verification of results.

Index words: Crown fit, marginal fit, FDP fit, fitting accuracy. 


\section{Introduction}

Fixed dental restorations mainly aim to restore function and aesthetic of lost intra-oral structures without jeopardizing the oral or general health of the patients [1]. Ill-fitting restoration is potentially harmful for abutment teeth and supporting periodontium. It provides access and host for oral bacteria adherence which can possibly cause secondary caries and /or traumatic gingival irritation $[2,3]$. Micro leakage through the dentinal tubules to the pulp chamber may lead to endodontic inflammation $[4,5]$. In addition, the restoration itself can be affected by the poor margin as variation in the fitting can create stress concentrations which may reduce the strength and long-term success of the restoration [6].

Clinically acceptable marginal gap of fixed restorations is difficult to be precisely identified through the literature. American Dental Association (ADA) specification No.8 [7] indicates that the thickness of luting cement for a dental crown should not exceed $25 \mu \mathrm{m}$ when using type I luting agent or $40 \mu \mathrm{m}$ when using type II luting agent. Although, marginal openings in this range are seldom achieved; it has been considered a clinical goal [8]. Christenson G (1971) agreed with the ADA specification [9]; others suggested modifying it. Fransson et al. [10] and Mclean et al. [11] argued that the clinically acceptable marginal gap after cementation should be less than $150 \mu \mathrm{m}$ and $120 \mu \mathrm{m}$ respectively. Additionally, Mclean et al. [11] examined the marginal fit of 1000 fixed restorations over a 5 years period and indicated that marginal gap less than $80 \mu \mathrm{m}$ is difficult to detect under clinical conditions.

Till this date, there is no conclusive evidence of optimum fit of contemporary ceramic systems. This topic is heavily investigated and fit values reported are widely diverse and range (in $\mu \mathrm{m}$ ) from 7.5 to $206.3[12,13]$. Such variation can be mainly attributed to lack of coherence about the definition of "fit" $[14,15]$, along with differences in methods employed 
to determine the fit [16-21], testing parameters followed [8, 13, 20, 22-29] and ceramic systems investigated [12, 23, 30-33].

Holmes et al. defined the internal gap as the measurement between the axial wall of the prepared tooth and the internal surface of the casting, while the same measurement at the margin is called "marginal gap" [34]. Furthermore, an angular combination of marginal gap and extension error is an "absolute marginal discrepancy" which specifically defines the linear distance from the surface finish line of the preparation to the margin of the restoration [34]. It is considered the best alternative measurement since it always be the largest error at the margin and reflects the total crown misfit at that point, both vertically and horizontally [34]. Measuring methods are different as they mainly span two approaches; invasive and noninvasive as in sectioning and direct view techniques respectively. Experimental set-ups can differ at the stage of testing the fit such as before or after cementation and involve other variables (i.e. sample size, measurements per specimen). Furthermore, ceramic systems differences in construction techniques (i.e. CAD/CAM, cast and Slip ceramics) can affect the restoration fitting accuracy [13, 15, 35-38].

A review paper published in 2010 reported the significance of some variables on the fit accuracy of fixed dental prostheses (FDPs) made of zirconia-based ceramics [39]. However, literature still lacks comprehensive review of most variables affecting the fit of wider range of available ceramic systems in contemporary dental practices. Therefore, the aim of this study is to review methods used to investigate marginal adaptation of crowns FDP, discuss testing variables employed and their influence on results. It covers all commonly used ceramic systems nowadays whether conventional or CAD/CAM and highlight all variables that affected accuracy of marginal gap measurements reported. 


\section{Methods}

Online search using libraries including Medline, Scopus and Ovid, to identify published works evaluated the fitting accuracy of indirect dental restorations, was conducted. Peer reviewed works published in English language in the period 1970 to December 2011 were only considered. The search was carried out using combinations of the following key/mesh words and phrases: "marginal accuracy", "marginal fit", "marginal gap", "marginal discrepancy", "precision of fit", "fitting accuracy", "crown", "bridge", "FPD”. The articles were initially evaluated by reading their abstracts, and further reviewed if they met the required inclusion criteria. The criteria included studies evaluating the fitting accuracy of any crown system through clear methodology and experimental conditions. In vitro and in vivo studies evaluating the fitting of any metal, metal-ceramic (MC), all-ceramic crown systems or crowns and FDPs made out of polymers as in all-polymer restorations (i.e. Fiber Reinforced Composites) through gap measurement were included. Exclusion criteria included:

i. Longitudinal prospective and retrospective clinical evaluations as they depend on a subjective evaluation according to dentists' or patients' satisfaction,

ii. Studies evaluated the marginal fitting through subjective tactile sensation; and

iii. Studies evaluated the internal fitting without reporting the marginal gap.

The selected articles were reviewed and grouped according to their methods as follows: 1 . direct view technique, 2. cross-sectioning technique, 3. impression replica technique, and 4. other methods. An in-depth consistent, clear and comprehensive analysis was generated to summarize the experimental variables among the studies, which could have influenced their reported results.

The analysis included: 
- Article demography (publication year, authors and the type of restoration tested),

$>$ Method of gap measurement,

Type of study (in vivo or in vitro),

Sample size,

Number of measurement per specimens,

Finish line design,

The stage at which the measurements were performed

1. Before or after cementation,

2. Before or after porcelain firing

The marginal gap recorded 


\section{Results}

The electronic search collectively revealed 277 articles; of which only 183 studies processed for review. The 94 articles did not meet the criteria were 66 studies of prospective or retrospective clinical evaluations, 6 studies did not mention all the required information about the measurement technique they used, 6 studies evaluated the fitting accuracy through the modified USPHS (United States Public Health Service) criteria and tactile sensation, 7 studies measured the internal fit only, and 9 studies evaluated the fit of partial crowns.

Generally, there was no conclusive evidence on the best methodology to evaluate the fitting accuracy of crowns and FDPs. A variety of methods and testing parameters have been used for this purpose including mainly direct view, cross-sectional view, and impression replica technique (Table 1). Furthermore, direct comparisons between studies were not possible as studies varied in their types (in vivo vs in vitro); sample size and number of measurements per specimen; preparation and finish line design; and when the gap was measured. Marginal adaptation varied among conventional and CAD/CAM ceramic systems as shown in Table 2 .

(Insert tables 1 and 2) 


\section{Discussion}

\section{Influence of measurement method}

As shown in Table 1, six methods are used. Of which direct view technique, was the most commonly used with $47.5 \%$ followed by cross-sectioning method $(23.5 \%)$ and impression replica technique (20.2\%). Direct view technique measures the gap between crown and die at the margin but not internally using microscope at different magnifications. This method does not incorporate any procedures on the crown-die assembly such as sectioning or replications of the cement space before measuring the gap; hence making it cheaper and less timeconsuming than other techniques and reduce the chance of error accumulation that may results from multiple procedures and ultimately impact the accuracy of results. However, this method can only be used in vitro as it requires direct examination of marginal gap under high power microscopy, which is crucial for the accuracy of this method. It has been reported that Scanning Electronic Microscopy (SEM) imaging was better than light microscopy to evaluate marginal gap of class II CAD/CAM inlays [195]. However, Groten et al. [53] reported, no significant difference between the accuracy of the two techniques, although according to the authors, SEM was able to provide more appropriate and realistic observations than a light microscope particularly with complex margin morphologies. Other microscopes used included digital microscopes [33], stereomicroscopes [55] and travelling microscopes [70]. They provided limited results from widely separated measuring points, hence calculated means usually demonstrate large standard deviations, and the results reported might be questionable [169].

Additional disadvantages include difficulty in selecting the points where the marginal opening is to be measured [178], inability to differentiate between tooth structure and toothcoloured cement or identifying the most apical part of the preparation margin [127]; margins of the crown and die may appear rounded when viewed under magnification [178]. 
In the impression replica technique, however, the crown is filled with low viscosity light body silicone material and seated on the die simulating the cementation procedure. After setting of the silicone material, the crown is gently removed from the die, and heavy body silicon is injected inside to stabilize the thin light body film before removing it from inside the crown. The light body silicon layer can then be sectioned and measured at different sites. Few researchers $[22,23,31,35,154,178,179]$ carried out some modifications on the impression replica technique by making external impression of the marginal gap after fixing the crown to its corresponding die. The impression was then poured with epoxy resin material and marginal gap was measured on the epoxy resin model. However, the impression replica technique has its constraints and inherent errors such as difficulty in identifying the crown margins and finishing lines, tearing of the elastomeric film upon removal from the crown [23], and mistakes in sectioning plane can lead to overestimated measurements [156]. Laurent et al. [196] found that if appropriate silicon is used, the cement space may be replicated and its thickness measured regardless of the localization. Similarly, Rahme et al. [191] reported no significant difference between silicon replica technique and sectioning technique in measuring the marginal gap of Procera crowns and advocated that using low-viscosity silicon for the replica technique can imitate the film thickness of a cemented crown applying glass ionomer cement.

The cross-sectioning method allows for direct measurement of the cement thickness and marginal gap in the vertical and horizontal planes; minimising chances of software or repositioning errors [182]. It also permits uninterrupted view of marginal gap adjacent to the connector in fixed dental prosthesis specimens [120]. However, this method does not allow long-term analysis and comparison of the results before and after different manufacturing stages using the same specimens [192] and the number of measurements is limited to the plane of sectioning which might not represent the complete fit of the crown [186]. 
Profilometry, on the other hand, is a nondestructive method. It presents the view of both the die and the specimen in the same focal plane on monitor, thus allowing for an accurate focus [24]. However, with profilometry, the thickness of the cement layer at the marginal areas can only be indirectly inferred, and in the case of sequential analysis, extreme care should be taken in repositioning the specimens, otherwise re-profiling discrepancies will occur [182]. Remaining methods including; Digimatic micrometer and Micro CT scan attracted least attention mainly due to inherent technical difficulties.

Cross checking gap measurements among these methods yielded great variances even within the same ceramic system as shown in Tables 1 and 2. For example, the marginal gap of InCeram Alumina crowns as reported in the literature ranges from 7.5 to $161 \mu \mathrm{m}[13,33]$. The significant differences in the techniques and variables used in the two studies could be an acceptable explanation of this wide range which might not reflect the actual fit of the restoration. However, comparing the results of similar studies $[24,25]$, which used almost the same technique and variables to measure the marginal gap of In-Ceram Alumina crown; reveals that the marginal gap of this crown system is $57 \mu \mathrm{m}$ and $49.8 \mu \mathrm{m}$ respectively. Both Balkaya et al [24] and Quintas et al [25] used profile projector and measured the marginal gap under similar condition (except the number of measurement per sample), and their results were comparable. The marginal gap of In-Ceram Zirconia (slip casting) FPD framework represents another example that shows how using different methods for measuring the marginal gap can influence the results. The marginal gap of this system was reported as 25 and $113 \mu \mathrm{m}[30,38]$. Although the two studies used same experimental set-ups, the methods of gap measurement were different; direct view technique and sectioning methods were used respectively. It is noticeable that the results reported do not offer information about the actual fit of this Zirconia system. Furthermore, Komine et al [181] and Marties-Rus et al [36] 
reported inconsistent results of In-Ceram Zirconia system (Vita YZ, Cerec inLab) when using replica technique $(91.6 \mu \mathrm{m})$ and direct view $(12.4 \mu \mathrm{m})$ techniques respectively.

Some studies used combinations of two methods; namely silicone replica and crosssectioning methods [191-194] and results were not conclusive. Tsitrou et al [193] used this combination to measure the marginal gap of Cerec crown. They reported mean marginal gaps on chamfer preparation (in um) of 94 and 91 and on shoulder preparation 91 and 77 when using silicon replica and cross-sectioning techniques respectively. Shearer et al [192] reported statistically significant differences in marginal gap of In-Ceram system when using sectioning and silicone replica techniques ( 8.3 and 28.6 um respectively). They advocated the accuracy of the sectioning technique above the silicone replica. However, Rahme et al [191], did not report significant differences between the above methods for Procera copings as marginal gap reported was 31.9 and 33.6 using sectioning and silicone replica techniques respectively.

\section{Influence of experimental set-up}

Researchers used different experimental set-ups and measured the marginal gaps under different conditions. Making the measurement in vivo or in vitro $[50,170,182]$, before or after cementation $[22,23,31,148]$, before or after veneering $[20,24,166]$, on a chamfer or shoulder finish line $[13,25,152]$, sample size and number of measurement per sample [63, 106] have been found to affect the marginal adaptation. Hence, differences in setting these conditions have led to inconsistencies in the results leading to conflicting conclusions concerning the clinical acceptability marginal fit of specific ceramic systems. The same crown system might be considered as having a perfect marginal fit according to one study

and having clinically unacceptable fit according to another. Table 2 shows the highest and lowest marginal gap values of various crown systems as reported in the literature. 
Clinically, several factors such as tooth preparation, impression technique and cementation methodology can complicate the testing process and deviate from the ideal situation [170] making the in vivo measurements more difficult than in vitro ones [182]. Also, in vitro studies offer standardized and optimized conditions in the experimental performance which may not be possible to achieve in vivo [50, 118].

\section{Influence of sample size:}

The adequacy of data is important issue for the success of any research. Sample size and the number of measurement per specimen and statistical test performed can consequently influence the strength of statistical analysis and thus conclusions made can be less relevant or invalid [45]. In addition, the larger the number of measurements per specimen, the greater the precision of the analysis will be [63]. It has been reported that individual measurements at different locations of the margin may reveal significant deviations from the mean, and may render the crowns clinically unacceptable even if the majority of the margin has an excellent fit [66].

Many studies which used small sample size reported large standard deviations compared to the mean value $[15,66,71,127]$ while using a larger sample size produced more consistent data with smaller standard deviation [45, 55, 107]. According to Groten et al [106], when investigating the marginal fit of fixed dental restoration, the smaller sample size can be compensated by larger number of measurement per sample. This conclusion can be demonstrated through Gonzalo et al's [27] and Lee et al's [28] studies which used a smaller sample size $(n=10)$ and compensated it with a large number of measurements per sample (60 and 50 measurements respectively) and achieved more consistent distribution of data with small standard deviations compared to the mean values. 
Groten et al. [106] used an empirical approach to sample size problem. They used a master steel die to fabricate ten all-ceramic crowns. Marginal gaps were then measured using scanning electronic microscopy before and after cementation starting with 230 measurements per crown. This number was reduced to smaller subsets following systematic and random approaches to verify their impact on the quality of the results. They reported that smaller data sizes led to accelerated rise in the standard of errors and divergent variability of the mean. Accordingly, 50 measurements per specimen were recommended to attain clinically significant information about marginal gap size regardless of the systematic or random approaches of the measurement sites, and at least 20 to 25 measurements per crown could be accepted depending on the required level of precision. Furthermore, a study that utilized a more sophisticated methodology of running 360 gap measurements at $360^{\circ}$ concluded that the minimum number of measurements required is 18 for in vitro evaluations and 90 for crowns constructed from impressions made intra-orally [63]. Therefore, 4-12 measurements per crown as used by several studies $[8,15,26,29,33,44,48,76]$ might be misleading.

\section{Influence of finish line:}

The effect of different finish line designs (i.e. shoulder, chamfer, feather edge, bevel) on the fit of crowns and FPDs has been widely investigated [13, 15, 25, 51, 115, 152, 155]. However, the conclusions of these studies seem to be contradictory. The possible influence of finish line configuration on the fitting of the crown according to Gavelis et al. [152] occurs during cementation. When the axial wall of the prepared tooth matches the axial wall of the internal crown surface, the escape pathway for cement diminishes, increasing the hydrostatic pressure within the crown until it equals the patient's biting pressure and prevent further seating of the crown [152]. If the cement has not completely set, it continues to escape until the particles at the axial walls prevent further seating [152]. Certain finish lines like shoulder 
seem to facilitate the escape of cement earlier in the cementation process, and thus improve crown fitting [152].

\section{Influence of cementing:}

Measuring the marginal gap of cemented or uncemented crowns can also influence the results of the measurement $[22,23,31,76,148]$. It is known that marginal discrepancy generally increases after cementation $[25,138]$ and that the cementation medium may discontinue the complete seating of full crown resulting in an insufficiently sealed margin of the restoration $[152,161]$. Many investigators reported a significantly higher marginal gap after cementation than that before cementation $[22,23,31,76,108]$. Furthermore, the cementation techniques such as uncontrolled finger pressure or overfilling of the crown with cement can cause uneven flow of cement with one axial wall having a thick film and the opposite wall having a thin film [136]. Moreover, the type of cement was reported to influence the fit of dental crowns $[54,109,187]$.

\section{Influence of veneering:}

Veneering process and its associated heat-treatment are known to affect the marginal fit of metal or ceramic core materials $[20,47,50,75,107,166]$. A greater value of marginal discrepancy has been reported to occur during the first firing stage [75, 107], with a greater effect of veneering process occurs in the horizontal plane [110]. Such distortion may clinically result in occlusal displacement of the prostheses and reduction of the load-bearing capacity of all-ceramic restorations [6]. In porcelain fused to metal restorations, design of the finish line affects the amount of marginal distortion occurs during firing [115]. According to Shillingburg et al. [115], the metal bulk in the shoulder design is greater and more rigid, and thus it shows less distortion than that of the chamfer. Difference in the bulk of metal between shoulder and chamfer, however, is probably too small to cause significantly different marginal distortion between the two designs [166]. Another explanation is the thermal 
incompatibility between metal and veneering porcelain. DeHoff et al. [197] reported, however, that the calculated marginal distortion values resulting from incompatibility of $\mathrm{Ni}$ $\mathrm{Cr}$ and Au-Pd alloys and three porcelain products were less than $21 \mu \mathrm{m}$ in all cases. This finding supports their hypothesis that the resultant metal distortion is not due to system incompatibility, and that poor creep resistance below the glass transition temperature of porcelain could be the major contributing factor [197]. Later, Anusavice et al. [58] demonstrated that incompatibility stress induced by a positive contraction mismatch was not the main cause of marginal distortion of PFM crowns, and suggested that external grinding and internal abrasive blasting of crowns are more likely causes of this effect.

In all-ceramic restorations, firing of the body porcelain occurs at temperatures several hundreds degrees above the glass transition temperature up to the sintering temperature of the veneering material [166]. Once achieved, temperature then drops off at a very high rate of $600{ }^{\circ} \mathrm{C} / \mathrm{min}$ which results in considerable stresses that can lead to distortion of the restoration [166]. Nevertheless, Kohorst et al. [20] showed by a simplified comparison between thermal expansion behaviors of the framework and veneering material of zirconia based FPDs, that thermal incompatibility is not sufficient to explain the resultant distortion.

Current work investigated the marginal adaptation of all commonly used ceramic systems nowadays whether conventional or CAD/CAM and highlighted all methods and experimental parameters that influence accuracy of marginal gap measurements of these systems through critically appraising the published work under structured criteria. However, it lacked reviewing current off-line published works on this topic, and reviewing published articles in 2012 (till this date) which could be considered as limitations of this review. Yet, 183 articles were reviewed in this study and in-depth analysis was provided. 


\section{Conclusions}

Within the limitations of this review, it can be concluded that there is a substantial lack of consensus relating to methods used to investigate marginal adaptation of crowns and fixed partial dentures. Considerable differences in testing techniques included experimental set-ups employed and ceramic systems investigated. Regardless, direct view technique is the most commonly used method and recorded the most reproducible results among different studies. Also, conducting an experimental set-up of testing minimum of 30 specimens of the same ceramic system at 50 measurements per specimen should produce reliable and accurate results. Additionally, using a combination of two measurement methods can be useful to verify and validate results. 


\section{References}

[1] Rosenstiel SF, Martin FL, Fujimoto J: Contemporary Fixed Prosthodontics. 4th ed. Mosby, St. Louis, Missouri, 2006.

[2] Bader J, Rozier R, Mcfall W, et al.: Effect of crown margins on periodontal conditions in regularly attending patients. J Prosthet Dent. 1991; 65: 75-79.

[3] Knoernschild KL, Campbell SD: Periodontal tissue responses after insertion of artificial crowns and fixed partial dentures. J Prosthet Dent. 2000; 84: 492-498

[4] Felton DA, Kanoy BE, Bayne SC, et al.: Effect of in vivo crown margin discrepancies on periodoontal health. J Prosthet Dent. 1991; 65: 357-364.

[5] Goodacre CJ, Bernal G, Rungcharassaeng K, et al.: Clinical complications in fixed prosthodontics. J Prosthet Dent. 2003; 90: 31-41.

[6] Tuntiprawon M, Wilson T: The effect of cement thickness on the fracture strength of all-ceramic crowns. Aust Dent J. 1995; 40: 17-21.

[7] American Dental Association: ANSI/ADA Specification No. 8 for zinc phosphate cement. In: Guide to dental materials and devices. 5th ed.Chicago: American Dental Association; 1970-1971.

[8] Holden JE, Goldstien G, Hittelman EL, et al.: Comparison of the marginal fit of pressable ceramic to metal ceramic restorations. J Prosthodont. 2009; 18: 645-648.

[9] Christensen G: Clinical and research advancements in cast-gold restorations. $J$ Prosthet Dent. 1971; 25: 62-68.

[10] Fransson B, Oilo G, Gjeitanger R: The fit of metal-ceramic crowns, a clinical study. Dent Mater. 1985; 1: 197-199.

[11] McLean JW, von Fraunhofer JA: The estimation of cement film thickness by an in vivo technique. Br Dent J. 1971; 131: 107-111.

[12] Kohorst P, Brinkmann H, Li J, et al.: Marginal accuracy of four-unit zirconia fixed dental prostheses fabricated using different computer-aided design/computer-aided manufacturing systems. Eur J Oral Sci. 2009; 117: 319-325.

[13] Pera P, Gilodi S, Bassi F, et al.: In vitro marginal adaptation of alumina porcelain ceramic crowns. J Prosthet Dent. 1994; 72: 585-590.

[14] Pelekanos S, Koumanou M, Koutayas S, et al.: Micro-CT evaluation of the marginal fit of different In-Ceram alumina copings. Eur J Esthet Dent. 2009; 4: 278-292.

[15] Suárez MJ, Villaumbrosia PG, Pradies G, et al.: Comparison of the marginal fit of Procera AllCeram crowns with two finish lines. Int J Prosthodont. 2003; 16: 229-232.

[16] Ayad MF: Effects of tooth preparation burs and luting cement types on the marginal fit of extracoronal restorations. J Prosthodont. 2009; 18: 145-151. 
[17] Giannetopoulos S, van Noort R, Tsitrou E: Evaluation of the marginal integrity of ceramic copings with different marginal angles using two different CAD/CAM systems. $J$ Dent. 2010; 38: 980-986.

[18] Örtorpa A, Jönssonb D, Mouhsenb A, et al.: The fit of cobalt-chromium three-unit fixed dental prostheses fabricated with four different techniques: a comparative in vitro study. Dent Mater. 2011; 27: 356-363.

[19] Hmaidouch R, Neumann P, Mueller WD: Influence of preparation form, luting space setting and cement type on the marginal and internal fit of CAD/CAM crown copings. Int $J$ Comput Dent. 2011; 14: 219-226.

[20] Kohorst P, Brinkmann H, Dittmer MP, et al.: Influence of the veneering process on the marginal fit of zirconia fixed dental prostheses. J Oral Rehabil. 2010; 37: 283-291.

[21] Kokubo Y, Nagayama Y, Tsumita M, et al.: Clinical marginal and internal gaps of InCeram crowns fabricated using GN-I system. J Oral Rehabil. 2005; 32: 753-758.

[22] Stappert C, Dai M, Chitmongkolsuk S, et al.: Marginal adaptation of three-unit fixed partial dentures constructad from pressed ceramic systems. Br Dent J. 2004; 196: 766-770.

[23] Wolfart S, Wegner SM, Al-Halabi A, et al.: Clinical evaluation of marginal fit of a new experimental all-ceramic system before and after cementation. Int J Prosthodont. 2003; 16: $587-592$.

[24] Balkaya MC, Cinar A, Pamul S: Influence of firing cycles on the margin distortion of 3 all-ceramic crown systems. J Prosthet Dent. 2005; 93: 346-355.

[25] Quintas AF, Oliveira F, Bottino MA: Vertical marginal discrepancy of ceramic copings with different ceramic materials, finish lines, and luting agents: an in vitro evaluation. J Prosthet Dent. 2004; 92: 250-257

[26] Fonseca JC, Henriques GE, Sobrinho LC, et al.: Stress-relieving and porcelain firing cycle influence on marginal fit of commercially pure titanium and titanium-aluminumvanadium copings. Dent Mater. 2003; 19: 686-691.

[27] Gonzalo E, Suárez MJ, Serrano B, et al.: A comparison of the marginal vertical discrepancies of zirconium and metal ceramic posterior fixed dental prostheses before and after cementation. J Prosthet Dent. 2009; 102: 378-384.

[28] Lee KB, Park CW, Kim KH, et al.: Marginal and internal fit of all-ceramic crowns fabricated with two different CAD/CAM systems. Dent Mater J 2008; 27: 422-426.

[29] Tan PL, Gratton D, Diaz-Arnold A, et al.: An in vitro comparison of vertical marginal gaps of CAD/CAM titanium and conventional cast restorations. J Prosthodont. 2008; 17: 378-383.

[30] Bindl A, Mörmann WH: Marginal and internal fit of all-ceramic CAD/CAM crown copings on chamfer preparations. J Oral Rehabil. 2005; 32: 441-447.

[31] Okutan M, Heydecke G, Butz F, et al.: Fracture load and marginal fit of shrinkagefree $\mathrm{ZrSiO} 4$ all-ceramic crowns after chewing simulation. J Oral Rehabil. 2006; 33: 827-832. 
[32] Reich S, Kappe K, Teschner H, et al.: Clinical fit of four-unit zirconia posterior fixed dental prostheses. Eur J Oral Sci. 2008; 116: 579-584.

[33] Sulaiman F, Chai J, Jameson LM, et al.: A comparison of the marginal fit of InCeram, IPS Empress, and Procera crowns. Int J Prosthodont. 1997; 10: 478-484.

[34] Holmes JR, Bayne SC, Holland GA, et al.: Considerations in measurement of marginal fit. J Prosthet Dent. 1989; 62: 405-408.

[35] Att W, Komine F, Gerds T, et al.: Marginal adaptation of three different zirconium dioxide three-unit fixed dental prostheses. J Prosthet Dent. 2009; 101: 239-247.

[36] Martínez-Rus F, Suárez MJ, Rivera B, et al.: Evaluation of the absolute marginal discrepancy of zirconia-based ceramic copings. J Prosthet Dent. 2011; 105: 108-114.

[37] Beuer F, Naumann M, Gernet W, et al:: Precision of fit: zirconia three-unit fixed dental prostheses. Clin Oral Investig. 2009; 13: 343-349.

[38] Bindl A, Mormann WH: Fit of all-ceramic posterior fixed partial denture frameworks in vitro. Int J Periodontics Restorative Dent. 2007; 27: 567-575.

[39] Abduo J, Lyons K, Swain M: Fit of zirconia fixed partial denture: a systematic review. J Oral Rehabil. 2010; 37: 866-876.

[40] Gonzalo E, Suárez MJ, Serrano B, et al.: Marginal fit of zirconia posterior fixed partial dentures. Oper Dent. 2008; 21: 398-399.

[41] Oyagüe C, Snchez-Jorge MI, Snchez TA, et al.: Influence of CAM vs. CAD/CAM scanning methods and finish line of tooth preparation in the vertical misfit of zirconia bridge structures. Am J Dent. 2009; 22: 79-83.

[42] Vermilyea SG, Kuffler MJ, Tamura JJ: Casting accuracy of base metal alloys. $J$ Prosthet Dent. 1983; 50: 651-653.

[43] Weaver JD, Johnson GH, Bales DJ: Marginal adaptation of castable ceramic crowns. J Prosthet Dent. 1991; 66: 747-753.

[44] Witkowski S, Komine F, Gerds T: Marginal accuracy of titanium copings fabricated by casting and CAD/CAM techniques. J Prosthet Dent. 2006; 96: 47-52

[45] Yeo IS, Yang JH, Lee JB: In vitro marginal fit of three all-ceramic crown systems. $J$ Prosthet Dent. 2003; 90: 459-464

[46] Campbell SD, Pelletier LB: Thermal cycling distortion of metal ceramics: part IIEtiology. J Prosthet Dent. 1992; 68: 284-289.

[47] Gemalmaz D, Alkumru H: Marginal fit changes during porcelain firing cycles. $J$ Prosthet Dent. 1995; 73: 49-54.

[48] Goldin EB, Boyd NW, Goldstien G, et al.: Marginal fit of leucite-glass pressible ceramic restorations and ceramic-pressed-to-metal restorations. J Prosthet Dent. 2005; 93: 143-147. 
[49] Shiratsuchi H, Komine F, Kakehashi Y, et al.: Influence of finish line design on marginal adaptation of electroformed metal-ceramic crowns. J Prosthet Dent. 2006; 95: 237242.

[50] Vigalo P, Fonzi F: An in vitro evaluation of fit of zirconium-oxide-based ceramic four-unit fixed partial dentures generated with three different CAD/CAM systems before and after porcelain firing cycles and after glaze cycles. J Prosthodont. 2008; 17: 621-626.

[51] Wöstmann B, Blöber T, Gouentenoudis M, et al.: Influence of margin design on the fit of high-precious restorations in patients. J Prosthet Dent. 2005; 33: 611-618.

[52] Contreras EF, Henriques GE, Giolo SR, et al.: Fit of cast commercially pure titanium and Ti-6Al-4V alloy crowns before and after marginal refinement by electrical discharge machining. J Prosthet Dent. 2002; 88: 467-472.

[53] Groten M, Girthofer S, Probster L: Marginal fit consistency of copy-milled allceramic crowns during fabrication by light and scanning electron microscopic analysis in vitro. J Oral Rehabil. 1997; 24: 871-881.

[54] Olivera AB, Saito T: The effect of die spacer on retention and fitting of complete cast crowns. J Prosthodont. 2006; 15: 243-249.

[55] Petteno D, Schierano G, Bassi F, et al.: Comparison of marginal fit of 3 different metal-ceramic systems: an in vitro study. Int J Prosthodont. 2000; 13: 405-408.

[56] Rinke S, Huls A, Jahn L: Marginal Accuracy and Fracture Strength of Conventional and Copy-Milled All-Ceramic Crowns. Int J Prosthodont. 1995; 8: 303-310.

[57] Abbate MF, Tjan AH, Fox WM: Comparison of the marginal fit of various ceramic crown systems. J Prosthet Dent. 1989; 61: 527-531.

[58] Anusavice KJ, Carroll JE: Effect of incompatibility stress on the fit of metal-ceramic crowns. J Dent Res. 1987; 66: 1341-1345.

[59] Behr M, Rosentritt M, Ledwinsky E, et al.: Fracture resistance and marginal adaptation of conventionally cemented fiber-reinforced composite three-unite FPDs. Int $J$ Prosthodont. 2002; 15: 467-472.

[60] Besimo C, Jeger C, Guggenheim R: Marginal adaptation of titanium frameworks produced by CAD/CAM techniques. Int J Prosthodont. 1997; 10: 541-546.

[61] Duncan JD: Casting accuracy of Nickel-Chromium alloys: marginal discrepancies. $J$ Dent Res. 1980; 59: 1194.

[62] Felton DA, Sulik WD, Holland GA, et al.: Marginal discrepancy changes at various stages of construction of three-unit porcelain-fused-to-metal fixed partial dentures. Dent Mater. 1988; 4: 296-301.

[63] Gassino G, Barone MS, Scanu M, et al.: Marginal adaptation of fixed prosthodontics: a new in vitro 360-degree external examination procedure. Int J Prosthodont. 2004; 17: 218223. 
[64] Hummert T, Barghi N, Berry T: Postcementation marginal fit of a new ceramic foil crown system J Prosthet Dent. 1992; 68: 766-770.

[65] Konstantoulakis E, Nakajima H, Woody R, et al.: Marginal fit and surface roughness of crowns made with an accelerated casting technique. J Prosthet Dent. 1998; 80: 337-345.

[66] Leong D, Chai J, Lautenschlager E, et al.: Marginal fit of machine-milled titanium and cast titanium single crowns Int J Prosthodont. 1994; 7: 440-747.

[67] Papazoglou E, Brantley WA, Johnston WM: Evaluation of high-temperature distortion of high-palladium metal-ceramic crowns. J Prosthet Dent. 2001; 85: 133-140.

[68] Pilathadka S, Slezák R, Vahalová D, et al.: Influence of different luting agents on the marginal discrepancy of Procera AllCeram alumina crown copings-an experimental study. Acta Medica. 2008; 15: 13-18.

[69] Rosentritt M, Plein T, Kolbeck C, et al.: In vitro fracture force and marginal adaptation of ceramic crowns fixed on natural and artificial teeth. Int J Prosthodont. 2000; 13: $387-391$.

[70] Albert FE, El-Mowafy OM: Marginal adaptation and microleakage of Procera AllCeram crowns with four cements. Int J Prosthodont. 2004; 17: 529-535.

[71] Baig MR, Tan KB-C, Nicholls JI: Evaluation of the marginal fit of a zirconia ceramic computer-aided machined (CAM) crown system. J Prosthet Dent. 2010; 104: 216-227.

[72] Polansky R, Heschl A, Arnetzl G, et al.: Comparison of the marginal fit of different all-ceramic and metal-ceramic crown systems: an in vitro study. J Stomat Occ Med. 2010; 3: 106-110.

[73] Richter-Snapp K, Aquillino SA, Svare CW, et al.: Change in marginal fit as related to margin design, alloy type, and porcelain proximity in porcelai-fused-to-metal restorations. $J$ Prosthet Dent. 1988; 60: 435-439.

[74] Romeo E, Iorio S, Storelli S, et al.: Marginal adaptation of full-coverage CAD/CAM restorations: in vitro study using a non-destructive method. Minerva Stomatol. 2009; 58: 6172 .

[75] Shokry T, Attia M, Ihab M, et al.: Effect of metal selection and porcelain firing on the marginal accuracy of titanium-based metal ceramic restorations. J Prosthet Dent. 2010; 103: 45-52.

[76] Suárez MJ, Lozano JF, Salido M, et al.: Marginal fit of Titanium metal-ceramic crowns. Int J Prosthodont. 2005; 18: 390-391.

[77] Tjan AH, Castelnuovo J, Shiotsu G: Marginal fidelity of crowns fabricated from six proprietary provisional materials. J Prosthet Dent. 1997; 77: 482-485.

[78] Lang BR, Gemalmaz D, Alkumru HN: Marginal fit changes during porcelain firing cycles. J Prosthet Dent. 1995; 73: 49-54. 
[79] Morris HF: Department of veterans affairs cooperative studies project No. 242. Quantitative and qualitative evaluation of the marginal fit of cast ceramic, porcelain-shoulder, and cast metal full crown margins. Participants of CSP No. 147/242. J Prosthet Dent. 1992; 67: 198-204.

[80] Sato T, Wohlwend A, Scharer P: Marginal fit in a "Shrink-Free" ceramic crown system. Int J Periodontics Restorative Dent. 1986; 6: 8-21.

[81] Boeckler AF, Stadler A, Setz JM: The significance of marginal gap and overextension measurement in the evaluation of the fit of complete crowns. J Contemp Dent Pract. 2005; 6: 26-37.

[82] Behr M, Rosentritt M, Latzel D, et al.: Comparison of three types of fiber-reinforced composite molar crowns on their fracture resistance and marginal adaptation. J Dent. 2001; 29: 187-196.

[83] Eden GT, Franklin OM, Powell JM, et al.: Fit of porcelain fused-to-metal crown and bridge castings. J Dent Res. 1979; 58: 2360-2368.

[84] Schneider DM, Levi MS, Mori DF: Porcelain shoulder adaptation using direct refractory dies. J Prosthet Dent. 1976; 36: 583-587.

[85] Schilling ER, Miller BH, Woody RD, et al.: Marginal gap of crowns made with a phosphate-bonded investment and accelerated casting method. J Prosthet Dent. 1999; 81: $129-134$

[86] Lomanto A, Weiner S: A comparative study of ceramic crown margins constructed using different techniques. J Prosthet Dent. 1992; 67: 773-777.

[87] Moore JA, Bargi N, Brukl CE, et al.: Marginal distortion of cast restorations induced by cementation. J Prosthet Dent. 1985; 54: 336-340.

[88] Mejia R, Tobon SM: Marginal fit of metal ceramic restorations subjected to a standardized postsoldering technique. J Prosthet Dent. 2000; 83: 535-539.

[89] Behr M, Rosentritt M, Mangelkramer M, et al.: The influence of different cements on the fracture resistance and marginal adaptation of all-ceramic and fiber-reinforced crowns. Int J Prosthodont. 2003; 16: 538-542.

[90] Jones MD, Dykema RW, Klein AI: Television micromeasurement of vented and nonvented cast crown marginal adaptation. Dent Clin North Am. 1971; 15: 663-677.

[91] Cho LR, Song HY, Koak JY, et al.: Marginal accuracy and fracture strength of ceromer/fiber-reinforced composite crowns: effect of variations in preparation design. $J$ Prosthet Dent. 2002; 88: 388-395.

[92] Cho L, Choi J, Jin Yi Y, et al.: Effect of finish line variants on marginal accuracy and fracture strength of ceramic optimized polymer/fiber-reinforced composite crowns. J Prosthet Dent. 2004; 91: 554-560. 
[93] Stricker E, Göhring TN: Influence of different posts and cores on marginal adaptation, fracture resistance, and fracture mode of composite resin crowns on human mandibular premolars. An in vitro study. J Dent. 2006; 34: 326-335.

[94] Kolbeck C, Rosentritt M, Behr M, et al.: In vitro study of fracture strength and marginal adaptation of polyethylene-fibre-reinforced-composite versus glass-fibrereinforced-composite fixed partial dentures. J Oral Rehabil. 2002; 29: 668-674.

[95] Iwai T, Komine F, Kobayashi K, et al.: Influence of convergence angle and cement space on adaptation of zirconium dioxide ceramic copings. Acta Odontol Scand. 2008; 66: 214-218.

[96] Mörmann W, Wolf D, Ender A, et al.: Effect of two self-adhesive cements on marginal adaptation and strength of esthetic ceramic CAD/CAM molar crowns. $J$ Prosthodont. 2009; 18: 403-410.

[97] Gonzalo E, Suarez MJ, Serrano B, et al.: A comparison of the marginal vertical discrepancies of zirconium and metal ceramic posterior fixed dental prostheses before and after cementation. J Prosthet Dent. 2009; 102: 378-384.

[98] Han HS, Yang HS, Lim HP, et al.: Marginal accuracy and internal fit of machinemilled and cast titanium crowns. J Prosthet Dent. 2011; 106: 191-197.

[99] Keyf F, Anil N: The effect of margin design on the marginal adaptation of temporary crowns. J Oral Rehabil. 1994; 21: 367-371.

[100] Nakamura T, Tanaka H, Kinuta S, et al.: In vitro study on marginal and internal fit of CAD/CAM all-ceramic crowns. Dent Mater J. 2005; 24: 456-459.

[101] Rocha SS, Nogueira F, Pieralini AR, et al.: Effect of phosphate-bonded investments on titanium reaction layer and crown fit. Braz Oral Res. 2010; 24: 147-152.

[102] Azar MS, Lehmann KM, Dietrich H, et al.: Effect of preparation depth differences on the marginal fit of zirconia crown copings: an in vitro study. Int J Prosthodont. 2011; 24: 264-266.

[103] Balkenhol M, Knapp M, Ferger P, et al.: Correlation between polymerization shrinkage and marginal fit of temporary crowns. Dent Mater. 2008; 24: 1575-1584.

[104] Bottino MA, Valandro LF, Buso L, et al.: The influence of cervical finish line, internal relief, and cement type on the cervical adaptation of metal crowns. Quintessence Int. 2007; 38: e425-432.

[105] Pak HS, Han JS, Lee JB, et al.: Influence of porcelain veneering on the marginal fit of Digident and Lava CAD/CAM zirconia ceramic crowns. J Adv Prosthodont. 2010; 2: 33-38.

[106] Groten M, Axmann D, Pröbster L, et al.: Determination of the minimum number of marginal gap measurements required for practical in vitro testing. J Prosthet Dent. 2000; 83: 40-49.

[107] Campbell SD, Sirakian A, Pelletier LB, et al.: Effects of firing cycle and surface finishing on distortion of metal ceramic castings. J Prosthet Dent. 1995; 74: 476-481. 
[108] Hamaguchi H, Cacciatore A, Tueller VM: Marginal distortion of the porcelainbonded-to-metal complete crowns: an SEM study. J Prosthet Dent. 1982; 47: 146-153.

[109] White SN, Kipnis V: Effect of adhesive luting agents on the marginal seating of cast restorations. J Prosthet Dent. 1993; 69: 28-31.

[110] Bridger DV, Nicholls JI: Distortion of ceramometal fixed partial dentures during the firing cycle. J Prosthet Dent. 1981; 45: 507-514.

[111] Al Wazzan K, Al-Nazzawi A: Marginal and internal adaptation of commercially pure titanium and titanium-aluminium-vanadium alloy cast restorations. J Contemp Dent Pract. 2007; 8: 1-9.

[112] Bhowmik H, Parkhedkar R: A comparison of marginal fit of glass infiltrated alumina copings fabricated using two different techniques and the effect of firing cycles over them. $J$ Adv Prosthodont. 2011; 3: 196-203.

[113] Boyle JJ, Naylor P, Blackman R: Marginal accuracy of metal ceramic restorations with porcelain facial margins. J Prosthet Dent. 1993; 69: 19-27.

[114] Nakamura T, Dei N, Kojima T, et al.: Marginal and internal fit of Cerec 3 CAD/CAM all-ceramic crowns. Int J Prosthodont. 2003; 16: 244-248.

[115] Shillingburg HT, Hobo S, Fisher DW: Preparation design and margin distortion in porcelain-fused-to-metal restorations. J Prosthet Dent. 1973; 29: 276-284.

[116] Beuer F, Aggstallera H, Edelhoffa D, et al.: Marginal and internal fits of fixed dental prostheses zirconia retainers. Dent Mater. 2009; 25: 94-102.

[117] Beuer F, Neumeier P, Naumann M: Marginal fit of 14-unit zirconia fixed dental prosthesis retainers. J Oral Rehabil. 2009; 36: 142-149.

[118] Beuer F, Richter J, Gernet W: Influence of preparation angle on marginal and internal fit of CAD/CAM-fabricated zirconia crown copings. Quintessence Int. 2009; 40: 243-250.

[119] Blackman R, Baes R, Barghi N: Marginal accuracy and geometry of cast titanium copings J Prosthet Dent. 1992; 67: 435-440.

[120] Kunii J, Hotta Y, Tamaki Y, et al.: Effect of sintering on the marginal and internal fit of CAD/CAM-fabricated zirconia frameworks. Dent Mater J. 2007; 26: 820-826.

[121] Oruç S, Tulunoglu Y: Fit of titanium and base metal alloy metal-ceramic crown. $J$ Prosthet Dent. 2000; 83: 314-318.

[122] Rahme HY, Adib SM, Zebouni E, et al.: Comparison of the fit of Procera crowns made from stone with those made from polyurethane resin. Gen Dent. 2009; 57: 171-179.

[123] Sorensen J: A standardized method for determination of crown margin fidelity. $J$ Prosthet Dent. 1990; 64: 18-24. 
[124] Fleming GJ, Dobinson MM, Landini G, et al.: An in-vitro investigation of the accuracy of fit of Procera and Empress crowns. Eur J Prosthodont Restor Dent. 2005; 13: $109-114$.

[125] Korkut L, Cotert HS, Kurtulmus H: Marginal, internal fit and microleakage of zirconia infrastructures: an in-vitro study. Oper Dent. 2011; 36: 72-79.

[126] Valderrama S, Roekel N, Andersson M, et al.: A comparison of the marginal and internal adaptation of titanium and gold-platinium-palladium metal ceramic crowns. Int $J$ Prosthodont. 1995; 8: 29-37.

[127] White SN, Yu Z, Tom JF, et al.: In vivo marginal adaptation of cast crowns luted with different cements. J Prosthet Dent. 1995; 74: 25-32.

[128] Alkumru H, Hullah WR, Marquis PM, et al.: Factors affecting the fit of porcelain jacket crowns. Br Dent J. 1988; 164: 39-43.

[129] Barone MS, Carpinteri B, Griffa B, et al.: Internal adaptation of fixed prosthodontics at shoulder preparation level evaluated by horizontal sections. Minerva Stomatol. 2006; 55: 381-389.

[130] Bronson MR, Lindquist TJ, Dawson DV: Clinical acceptability of crown margins versus marginal gaps as determined by pre-doctoral students and prosthodontists. $J$ Prosthodont. 2005; 14: 226-232.

[131] Comlekoglu M, Dundar M, Ozcan M, et al.: Influence of cervical finish line type on the marginal adaptation of zirconia ceramic crowns. Oper Dent. 2009; 34: 586-592.

[132] Ettinger RL, Kambhu PP, Asmussen CM, et al.: An in vitro evaluation of the integrity of stainless steel crown margins cemented with different luting agents. Spec Care Dentist. 1998; 18: 78-83.

[133] Ferrari M: Cement thickness and microleakage under dicor crowns: an in vivo investigation. Int J Prosthodont. 1991; 4: 126-131.

[134] Gelbard S, Aoskar Y, Zalkind M, et al.: Effect of impression materials and techniques on the marginal fit of metal castings J Prosthet Dent. 1994; 16: 1-6.

[135] Lin MT, Sy MJ, Muñoz CA, et al.: The effect of tooth preparation form on the fit of Procera copings. Int J Prosthodont. 1998; 11: 580-590.

[136] Pilo R, Cardash HS: In vivo retrospective study of cement thickness under crowns. $J$ Prosthet Dent. 1998; 79: 621-625.

[137] Schaerer P, Sato T, Wohlwend A: A comparison of the marginal fit of three cast ceramic crown systems. J Prosthet Dent. 1988; 59: 534-542.

[138] Byrne G: Influence of finish line form on crown cementation. Int J Prosthodont. 1992; 5: 137-144.

[139] Holmes JR, Sulik WD, Holland GA, et al.: Marginal fit of castable ceramic crowns. $J$ Prosthet Dent. 1992; 67: 594-599. 
[140] Bindl A, Windisch S, Mörmann WH: Full-ceramic CAD/CIM anterior crowns and copings. Int J Comput Dent. 1999; 2: 97-111.

[141] Syu JZ, Byrne G, Laub LW, et al.: Influence of finish-line geometry on the fit of crowns. Int J Prosthodont. 1993; 6: 25-30.

[142] Naert I, Van Der Donck A, Beckers L: Precision of fit and clinical evaluation of allceramic full restorations followed between 0.5 and 5 years. J Oral Rehabil. 2005; 32: 51-57.

[143] Lopes MB, Consani S, Sinhoreti MAC, et al.: Influence of recasting palladium-silver alloy on the fit of crowns with different marginal configurations. J Prosthet Dent. 2005; 94: 430-434.

[144] Byrne G, Laub LW, Hu JY, et al.: The fit of fixed partial dentures joined by infrared soldering. J Prosthet Dent. 1992; 68: 591-596.

[145] Givens EJ, Jr., Neiva G, Yaman P, et al.: Marginal adaptation and color stability of four provisional materials. J Prosthodont. 2008; 17: 97-101.

[146] Beuer F, Edelhoff D, Gernet W, et al.: Effect of preparation angles on the precision of zirconia crown copings fabricated by CAD/CAM system. Dent Mater J. 2008; 27: 814-820.

[147] Grenade C, Mainjot A, Vanheusden A: Fit of single tooth zirconia copings: comparison between various manufacturing processes. J Prosthet Dent. 2011; 105: 249-255.

[148] Hung SH, Hung KS, Eick DJ, et al.: Marginal fit of porcelain-fused-to-metal and two types of ceramic crown. J Prosthet Dent. 1990; 63: 26-31.

[149] Holmes JR, Pilcher ES, Rivers JA, et al.: Marginal fit of electroformed ceramometal crowns. J Prosthodont. 1996; 5: 111-114.

[150] Buchanan WT, Svare CW, Turner KA: The effect of repeated firings and strength on marginal distortion in two ceramometal systems. J Prosthet Dent. 1981; 45: 502-506.

[151] Tjan AH, Li T, Logan GI, et al.: Marginal accuracy of complete crowns made from alternative casting alloys. J Prosthet Dent. 1991; 66: 157-164.

[152] Gavelis JR, Morency JD, Sozio RB: The effects of various finish line preparations on the marginal seal and occlusal seat of full crown preparations. J Prosthet Dent. 1981; 45: 138-145.

[153] Jacques LB, Ferrari M, Cardoso PE: Microleakeage and resin cement film thickness of luted all-ceramic and gold electroformed porcelain-fused-to-metal crowns. J Adhes Dent. 2003; 5: 145-152.

[154] Tinschert J, Natt G, Mautsch W, et al.: Marginal fit of alumina- and zirconia-based fixed partial dentures produced by a CAD/CAM system. Oper Dent. 2001; 26: 367-374.

[155] Belser UC, MacEntee MI, Richter WA: Fit of three porcelain-fused-to-metal marginal designs in vivo: a scanning electron microscope study. J Prosthet Dent. 1985; 53: 24-29. 
[156] Coli P, Karlsson S: Fit of a new pressure sintered zirconium dioxide coping. Int $J$ Prosthodont. 2004; 17: 59-64.

[157] Davis SH, Kelly JR, Campbell SD: Use of an elastomeric material to improve the occlusal seat and marginal seal of cast restorations J Prosthet Dent. 1989; 62: 288-291

[158] Harris JR, Wickens IL: A comparison of the fit of spark-eroded titanium copings and cast gold alloy copings. Int J Prosthodont. 1994; 7: 348-355.

[159] Leal MB, Paulino SM, Pagnano VO, et al.: Influence of investment type and sprue number on the casting accuracy of titanium crown margins. J Prosthet Dent. 2006; 95: 42-49.

[160] Linsen S, Wirtz D, Fischer C, et al.: Optimization of the marginal gap of all-ceramic restorations and gold crowns by ultrasonic activated, suspended Al2O3 powder. Am J Dent. 2009; 22: 255-258.

[161] Gu XH, Kern M: Marginal discrepancies and leakage of all-ceramic crowns: influence of luting agents and aging conditions. Int J Prosthodont. 2003; 16: 109-116.

[162] Kokubo Y, Ohkubo C, Tsumita M, et al.: Clinical marginal and internal gaps of Procera AllCeram crowns. J Oral Rehabil. 2005; 32: 526-530.

[163] Nakamura T, Nonaka M, Maruyama T: In vitro fitting accuracy of copy-milled alumina cores and all-Ceramic crowns. Int J Prosthodont. 2000; 13: 189-193.

[164] Quante K, Ludwig K, Matthias K: Marginal and internal fit of metal-ceramic crowns fabricated with a new laser melting technology. Dent Mater. 2008; 24: 1311-1315.

[165] Chan D, Blackman R, Kaiser D, et al.: The effect of sprue design on the marginal accuracy of titanium castings. J Oral Rehabil. 1998; 25: 424-429.

[166] Dittmer MP, Borchers L, Stiesch M, et al.: Stress and distortions within zirconia-fixed dental prostheses due to the veneering process. Acta Biomater. 2009; 5: 3231-3239.

[167] Grey NJ, Piddock V, Wilson MA: In vitro comparison of conventional crowns and a new all-ceramic system. J Dent. 1993; 21: 47-51.

[168] Karlsson S: The fit of Procera titanium crowns. An in vitro and clinical study. Acta Odontol Scand. 1993; 51: 129-134.

[169] May KB, Russell MM, Razzoog ME, et al.: Precision of fit: the Procera AllCeram crown. J Prosthet Dent. 1998; 80: 394-404.

[170] Mou SH, Chai T, Wang JS, et al.: Influence of different convergence angles and tooth preparation heights on the internal adaptation of Cerec crowns. J Prosthet Dent. 2002; 87: 248-255.

[171] Assif D, Antopolski B, Helft M, et al.: Comparison of methods of clinical evaluation of the marginal fit of complete cast gold crowns J Prosthet Dent. 1985; 54: 20-24.

[172] Boening K, Reppel PD, Walter M: Non-cast titanium restorations in fixed prosthodontics. J Oral Rehabil. 1992; 19: 281-287. 
[173] Bindl A, Mörmann WH: Clinical and SEM evaluation of all-ceramic chair-side CAD/CAM generated partial crowns. Eur J Oral Sci. 2003; 111: 163-169.

[174] Reich S, Uhlen S, Gozdowski S, et al.: Measurement of cement thickness under lithium disilicate crowns using an impression material technique. Clin Oral Investig. 2010; 15: 521-526.

[175] Reich S, Wichmann M, Nkenke E, et al.: Clinical fit of all-ceramic three-unit fixed partial dentures, generated with three different CAD/CAM systems. Eur J Oral Sci. 2005; 113: $174-179$.

[176] Boening K, Wolf BH, Schmidt AE: Clinical fit of Procera AllCeram crowns. $J$ Prosthet Dent. 2000; 84: 419-424.

[177] Kokubo Y, Tsumita M, Kano T, et al.: Clinical marginal and internal gaps of zirconia all-ceramic crowns. J Prosthodont Res. 2011; 55: 40-43.

[178] Beschnidt SM, Strub JR: Evaluation of the marginal accuracy of different all-ceramic crown systems after simulation in the artificial mouth. J Oral Rehabil. 1999; 26: 582-593.

[179] Kern M, Schaller H, Strub JR: Marginal fit of restorations before and after cementation in vivo. Int J Prosthodont. 1993; 6: 585-591.

[180] Scotti R, Cardelli P, Baldissara P, et al.: Clinical fitting of CAD/CAM zirconia single crowns generated from digital intraoral impressions based on active wavefront sampling. $J$ Dent (Epub ahead of print). 2011.

[181] Komine F, Gerds T, Witkowski S, et al.: Influence of framework configuration on the marginal adaptation of zirconium dioxide ceramic anterior four-unit frameworks. Acta Odontol Scand. 2005; 63: 361-366.

[182] Good M, Mitchell C, Pintado M, et al.: Quantification of all-ceramic crown margin surface profile from try-in to 1-week post-cementation. J Dent. 2009; 37: 65-75.

[183] Limkangwalmongkol P, Chiche GJ, Blatz MB: Precision of fit of two margin designs for metal-ceramic crowns. J Prosthodont. 2007; 16: 233-237.

[184] Limkangwalmongkol P, Kee E, Chiche GJ, et al.: Comparison of marginal fit between all-porcelain margin versus alumina-supported margin on Procera alumina crowns. $J$ Prosthodont. 2009; 18: 162-166.

[185] Tao J, Yoda M, Kimuraa K, et al.: Fit of metal ceramic crowns cast in Au-1.6 wt\% Ti alloy for different abutment finish line curvature. Dent Mater. 2006; 22: 397-404.

[186] Mitchell CA, Pintado MR, Douglas WH: Nondestructive, in vitro quantification of crown margins. J Prosthet Dent. 2001; 85: 575-584.

[187] Clark MT, Richards MW, Meiers JC: Seating accuracy and fracture strength of vented and nonvented ceramic crowns luted with three cements. J Prosthet Dent. 1995; 74: 18-24.

[188] Piemjai M: Effect of seating force, margin design, and cement on marginal seal and retention of complete metal crowns. Int J Prosthodont. 2001; 14: 412-416. 
[189] Borba M, Cesar P, Griggs J, et al.: Adaptation of all-ceramic fixed partial dentures. Dent Mater. 2011; 27: 1119-1126.

[190] Rungruanganunt P, Kelly RJ, Adams D: Two imaging techniques for 3-D quantification of pre-cementation space for CAD/CAM crowns. J Dent. 2010; 38: 995-1000.

[191] Rahme HY, Tehini GE, Adib SM, et al.: In vitro evaluation of "replica technique" in the measurement of the fit of Procera crowns. J Contemp Dent Pract. 2008; 9: 25-32.

[192] Shearer B, Gough MB, Setchell DJ: Influence of marginal configuration and porcelain addition on the fit of In-Ceram crowns. Biomaterials. 1996; 17: 1891-1895.

[193] Tsitrou EA, Northeast SE, Noort R: Evaluation of the marginal fit of three margin designs of resin composite crowns using CAD/CAM. J Dent. 2007; 35: 68-73.

[194] Tjan AH, Li T, Logan G, et al.: Marginal accuracy of complete crowns made from alternative casting alloys. J Prosthet Dent. 1991; 66: 157-164.

[195] Schmalz G, Federlin M, Reich E: Effect of dimension of luting space and luting composite on marginal adaptation of a class II ceramic inlay. Int J Prosthodont. 1995; 11: 333-339.

[196] Laurent M, Scheer P, Dejou J, et al.: Clinical evaluation of the marginal fit of cast crowns-validation of the silicon replica method. J Oral Rehabil. 2008; 35: 116-122.

[197] DeHoff PH, Anusavice KJ: Effect of metal design on marginal distortion of metalceramic crowns. J Dent Res. 1984; 63: 1327-1331. 
Table 1: Analysis of marginal adaptation reported by various methods for different all-ceramic systems

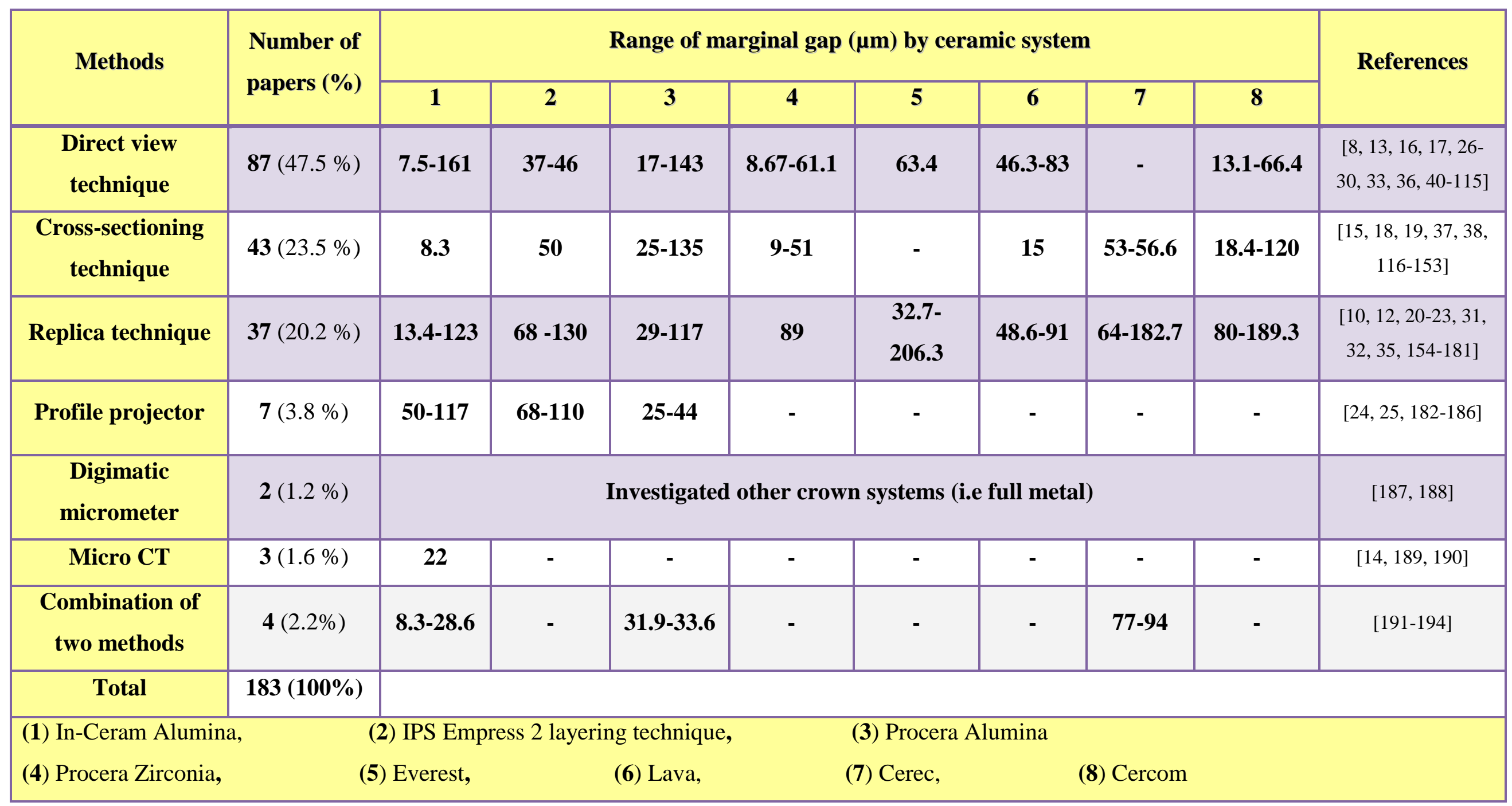




\begin{tabular}{|c|c|c|c|}
\hline \multicolumn{2}{|c|}{ Ceramic system } & \multirow{2}{*}{$\begin{array}{c}\begin{array}{c}\text { Mean Marginal } \\
\text { gap }(\boldsymbol{\mu m})\end{array} \\
7.50-161\end{array}$} & \multirow{2}{*}{$\frac{\text { References }}{[13,33]}$} \\
\hline $\begin{array}{l}\text { Traditional systems (i.e. } \\
\text { follows conventional }\end{array}$ & In-Ceram Alumina & & \\
\hline $\begin{array}{l}\text { construction methods } \\
\text { like casting or slipping }\end{array}$ & $\begin{array}{c}\text { IPS Empress } 2 \text { staining } \\
\text { technique }\end{array}$ & $97-130$ & {$[23,161]$} \\
\hline techniques) & $\begin{array}{l}\text { IPS Empress } 2 \text { layering } \\
\text { technique }\end{array}$ & $36.6-110$ & {$[25,71]$} \\
\hline & $\begin{array}{l}\text { In-Ceram Zirconia Slip } \\
\text { casting } \\
\end{array}$ & $25-113$ & {$[30,38]$} \\
\hline & Procera (Alumina) & $17-143$ & {$[15,30]$} \\
\hline \multirow[t]{4}{*}{ CAD/CAM systems } & Cerec & $53-182.7$ & {$[12,38]$} \\
\hline & Lava & $15-91$ & {$[32,37]$} \\
\hline & Everest & $32.7-206.3$ & {$[12,31]$} \\
\hline & Procera (Zirconia) & $8.67-89$ & {$[35,36]$} \\
\hline
\end{tabular}

